\title{
Yozgat ili elma ve armut üretim alanlarında ateş yanıklığı [Erwinia amylovora (Burrill) Winslow et al.] hastalığının mevcut durumunun belirlenmesi
}

Determination of current statues of bacterial fire blight [Erwinia amylovora (Burrill) Winslow et al.] disease in apple and pear production areas in Yozgat Province

\section{Murat ÖZTÜRK ${ }^{1}$ (D) , Soner SOYLU ${ }^{2}$, Zeliha KAYAASLAN ${ }^{1}$ iD}

${ }^{1}$ Yozgat Bozok University, Faculty of Agriculture, Department of Plant Protection, Yozgat, Turkey.

${ }^{1}$ Hatay Mustafa Kemal University, Faculty of Agriculture, Department of Plant Protection, Antakya-Hatay, Turkey.

MAKALE BILGISI / ARTICLE INFO

Makale tarihçesi / Article history:

DOI: $10.37908 / m k u t b d .844261$

Geliş tarihi /Received:21.12.2020

Kabul tarihi/Accepted:20.01.2021

\section{Keywords:}

Bacterial disease, fire blight, Erwinia amylovora, Yozgat province, molecular identification.

\footnotetext{
Corresponding author: Murat ÖZTÜRK
}

$\bowtie:$ muratzm66@gmail.com

\section{ÖZET / A B STRACT}

\begin{abstract}
Aims: This study was conducted to determine current statues of bacterial fire blight disease in apple and pear production areas of Yozgat province in 2018.

Methods and Results: The trees in the surveyed apple and pear orchards were evaluated for disease, the disease agent was isolated from the infected plants and identified by morphological, biochemical, physiological and molecular methods. Among 86 bacterial isolates obtained from 45 infected plant samples, 20 isolates were determined as Erwinia amylovora according to result of morphological, biochemical, physiological and molecular tests. The disease prevalence in the surveyed pear orchards was $91 \%$, the incidence rate $20 \%$, and the disease severity $29 \%$, while disease prevalence in the surveyed apple orchards was $70 \%$, the incidence rate $0.87 \%$, and the disease severity $5.93 \%$.

Conclusions: It has been determined that the disease is more common in pear orchards compared to apple orchards in Yozgat province, similarly, the severity of the disease is higher in pear trees than in apple trees.

Significance and Impact of the Study: Overall results obtained reveal the current situation of the bacterial fire blight disease in Yozgat province, the necessity of taking serious measures against the disease in newly established orchards has once again come to the fore with this study due to the serious problems encountered on pear trees.
\end{abstract}

\footnotetext{
Atıf / Citation: Öztürk M, Soylu S, Kayaaslan Z (2021) Yozgat ili elma ve armut üretim alanlarında ateş yanıklığı [Erwinia amylovora (Burrill) Winslow et al.] hastalığının mevcut durumunun belirlenmesi. MKU. Tar. Bil. Derg. 26(1) : 200-210. DOI: 10.37908/mkutbd.844261
}

\section{GiRiş}

Ülkemiz toplam tarım alanlarının yaklaşık \%14'ünde meyve yetiştiriciliği yapılmaktadır. Yumuşak çekirdekli meyveler grubunda yer alan elma ve armut, üretim ve alan bakımından ülkemiz için büyük potansiyele sahiptir (Gül ve Akpınar, 2006; Bashimov, 2016). Ülkemizde 2000 yılı itibariyle elma üretiminde \%18, armut üretiminde $\% 23$ oranında bir büyüme kaydedilmiştir. FAO'nun 2018 yılı üretim istatistiklerine göre, Dünya genelinde 4904305 ha alandan 86142197 ton elma üretimi gerçekleştirilmiştir. Ülkemiz genelinde 174690 ha alanda 3625960 ton elma üretimi yapılmış olup, üretim bakımından Türkiye dünya sıralamasında Çin, Amerika Birleşik Devletleri (A.B.D) ve Polonya ülkelerinden sonra 4. sırada yer almıştır. Armut üretiminde ise aynı yıl dünya genelinde 1381923 (ha) alanda 23733772 ton üretim yapılmıştır. Aynı yıl içinde ülkemiz genelinde armut üretimi 26389 ha alanda 519 451 ton gerçekleşmiş olup, üretim bakımından Türkiye 
dünya sıralamasında Çin, A.B.D, İtalya ve Arjantin ülkelerinden sonra 5. sırada yer almıştır (FAO, 2018).

Yozgat ilinde 1268 (ha) alanda 14601 ton elma üretimi yapılmakta olup ağaç sayısı toplamı 646993 adettir. Armut üretimi ise 155 (ha) alanda 1711 ton üretilmekte ve toplam ağaç sayısı 72254 adettir (TUiK, 2016). Yozgat ilinde meyvecilik entegrasyon projeleri yapılmakta olup meyve üretimi daha büyük bir potansiyeli işaret etmektedir (Anonim, 2017).

Yumuşak çekirdekli meyvelerin verim ve kalitesini etkileyen birçok viral, fungal ve bakteriyel kökenli hastalıklar bulunmaktadır. Bu hastalıklar içerisinde özellikle bakteriyel hastalıklar arasında en tahripkâr olanı ateş yanıklığı hastalığıdır. Dünya genelinde yapılan bir araştırmaya göre dünyada bitki verimi ve kalitesini etkileyen en önemli ilk 10 bakteriyel kökenli hastalık içerinde yer alan ateş yanıklığı hastalığına Erwinia amylovora (Burrill) (Winslow et al.) isimli bakteri neden olmaktadır (Van der Zwet ve Beer, 1992; Van der Zwet ve Bonn, 1999; Cabrefiga ve Montesinos, 2005; Mansfield ve ark., 2012). E. amylovora, Enterobacteriaceae familyasında yer alan, gram negatif, fakültatif anaerob, çubuk şekilli ve peritrik kamçılı bir bakteriyel etmendir (Schaad ve ark., 2001). Hastalık etmeninin Rosaceae familyasında yer alan 37 cinse ait 129 bitki türünde hastalığa neden olduğu bildirilmektedir (Van der Zwet ve Keil, 1979). E. amylovora'nın ekonomik zarara neden olduğu en önemli konukçu meyve ağaçları arasında armut (Pyrus spp.), elma (Malus spp.), ayva (Cydonia spp.), muşmula (Mespilus germanica), yenidünya (Eriobotrya japonica) bitkileri yer almaktadır. Hastalık etmeni ayrıca alıç (Crataegus spp.), dağ muşmulası (Cotoneaster spp.), kuşburnu (Rosa spp.) ve kuş üvezi (Sorbus spp.) bitkilerinde de rapor edilmiştir (Van der Zwet ve Beer, 1992; Momol ve Zeller, 1992; Sobiczewski ve ark., 1997; Baştaş, 2012; Baştaş ve Şahin, 2014).

E. amylovora, konukçu bitkide, çiçek tomurcukları, sürgün, ana dallar, gövde, ve köklerde oluşturduğu enfeksiyon nedeniyle ağaçların kısa sürede ölümüne sebep olur (Van der Zwet 1986; Van der Zwet ve Beer, 1992; Agrios, 2005). Patojen sürgün, meyve, ağaç kabuğu gibi çeşitli bitki dokularında damlacıklar halinde 'ooze' adı verilen bakteriyel akıntılar (eksudat) oluşturmaktadır. E. amylovora etmeni, dünyada ilk izole edilen bakteriyel hastalık etmeni olup birçok ülkede karantinaya tabi organizmadır. Önemli karantina tedbirleri gerektiren E. amylovora etmeni EPPO-A2 karantina listesinde yer almaktadır (Rosselo ve ark., 2006).

Ateş yanıklığı hastalığı ülkemizde ilk olarak 1985 yılında Afyon ili (Sultandağ ilçesinde) armut bahçelerinde tespit edilmiştir (Öktem ve Benlioğlu, 1988). Orta Doğu, Balkanlar ve Akdeniz bölgelerinde ateş yanıklığının yayılışı, 1982 yılında Mısır ülkesinden hızlıca yayılan epidemiden kaynaklı olabileceği bildirilmiştir (Momol ve Zeller, 1992). Ülkemize giriş yaptıktan kısa bir süre sonunda, E. amylovora etmeni elma, armut, ayva ve yenidünya ağaçlarında epidemilere yol açarak Akdeniz, Ege, Marmara, Karadeniz, Güney Doğu, iç Anadolu, Doğu Anadolu Bölgelerinde bir çok ilimizde farklı oranlarda zarara neden olacak şekilde hastalığa neden olmuştur (Tokgönül ve Çınar, 1991; Momol ve Zeller, 1992; Demir ve Gündoğdu, 1993; Baştaş ve Katırcıoğlu; 1999; Benlioğlu ve Özakman, 1999; Mirik, 2000; Baştaş, 2012; Tunalı, 2013; Aktepe ve ark., 2014; Baştaş ve Şahin, 2014; Aktepe, 2017; Kıpçak ve Akköprü, 2017; Uzer, 2017). Ülkemizin önemli armut ve elma yetiştiriciliği yapılan illerinde hastalığın yaygınlığı ve etmenin karakterizasyonu üzerine yapılan çalışmalara bakıldığında, hastalık etmeninin Yozgat ilindeki yaygınlık durumunu bildiren önceden yapılmış detaylı bir çalışmanın olmadığı görülmüştür.

Yapılan bu çalışmada, 2018 yılı Yozgat ili genelinde yetiştiriciliği yapılan elma ve armut ağaçlarından ateş yanıklığı hastalığı etmeninin izolasyonu, morfolojik, biyokimyasal, fizyolojik ve moleküler tanılanmasının yanı sıra, hastalık etmeninin il genelinde yaygınlığı, enfekteli bahçelerde bulunma oranı ve neden olduğu hastalık şiddetinin belirlenmesi amaçlanmıştır.

\section{MATERYAL ve YÖNTEM}

\section{Hastalık surveyi}

Survey çalışmaları, 2018 yılı Mayıs-Ağustos ayları arasında Yozgat ili Çekerek, Kadışehri, Merkez, Sarıkaya ve Sorgun ilçelerinde elma ve armut yetiştirilen alanlarda yapılmıştır. Surveyler 5 ilçeye bağlı 12 farklı köyde üretimi yapılan 30 farklı elma bahçesi ile 11 farklı armut bahçesinde yapılmıştır. Survey yapılan bahçelerde toplam 1890 elma ve 820 armut ağacında hastalık yönünden gözlem yapılmıştır (Çizelge 2 ).

Survey çalışmalarında incelenecek ağaç sayısı, ilçelerdeki ağaç sayısı varlığı göz önüne alınarak her survey merkezinde toplam ağaç sayısının en az $\% 2$ 'sini içine alacak şekilde belirlenmiştir. Hastalık şiddeti, 1-10 skalası kullanılarak ağaçlar üzerindeki enfeksiyon ifade edilmiştir (Van der Zwet ve Keil, 1979). Incelenen bahçelerdeki hastalığın, yaygınlığı ( $\mathrm{P}$, prevelance), bulunma oranı ( $\mathrm{I}$, incidence) ve hastalık şiddeti $(\mathrm{S}$, severity) tartılı ortalama yöntemine göre hesaplanmıştır (Bora ve Karaca, 1970). Tipik hastalık belirtileri gösteren 45 farklı örnek, izolasyon işlemi için laboratuvara 
getirilerek izolasyon çalışmaları tamamlanana kadar $+4^{\circ} \mathrm{C}^{\prime}$ de buzdolabında saklanmıştır.

\section{Hastalıklı örneklerden bakteriyel etmenin izolasyonu} Hastalıklı ve sağlıklı kısmı içeren yaprak ve sürgün dokularının yüzeysel dezenfeksiyonu, örneklerin \%1'lik $\mathrm{NaOCl}$ içerisinde 2-3 (dak.) süreyle bekletilmek suretiyle uygulanmıştır. Örnekler 3 kez steril su ile durulandıktan sonra fizyolojik serum (\%0.85'lik $\mathrm{NaOCl}$ çözeltisi) bulunan steril plastik doku ezme poşetlerine konularak havan tokmağı yardımıyla ezilerek homojenize edilmiştir. Homojenize edilmiş dokulardan 45-60 (dak.) sonra elde edilen süspansiyonlar King $\mathrm{B}$ agar (proteose peptone $10.0 \mathrm{~g} \mathrm{~L}^{-1}, \mathrm{~K}_{2} \mathrm{HPO}_{4} 1.5 \mathrm{~g} \mathrm{~L}^{-1}, \mathrm{MgSO}_{4} .7 \mathrm{H}_{2} \mathrm{O} 1.5 \mathrm{~g} \mathrm{~L}^{-}$ 1 , agar $15 \mathrm{~g} \mathrm{~L}^{-1}$, gliserol $15 \mathrm{ml} \mathrm{L}^{-1}$, cycloheximide $100 \mathrm{mg}$ $\mathrm{L}^{-1}$ ) besi yerine çizgi ekim yapılarak $26^{\circ} \mathrm{C}^{\prime}$ de $24-48$ saat inkübe edilmiştir (King ve ark., 1954). Enfekteli 45 adet örnekten 86 adet bakteriyel koloni saflaştırılarak biyokimyasal, fizyolojik ve moleküler tanı testleri için $\% 30^{\prime}$ luk gliserolde $-20^{\circ} \mathrm{C}^{\prime}$ de muhafaza edilmiştir.

\section{Biyokimyasal ve fizyolojik testler}

Hastalık etmeninin biyokimyasal ve fizyolojik tanılanmasında, potasyum hidroksit $(\mathrm{KOH}), \% 5$ 'lik Sukroz Nutrien Agar (SNA) besi yeri üzerinde levan tip koloni, oksidaz, arginine dehidrolaz, oksidasyonfermentasyon, indol oluşumu ve jelatinin hidrolizi testleri uygulanmıştır. Etmenin $36^{\circ} \mathrm{C}^{\prime}$ de gelişebilme, $\% 5^{\prime}$ lik $\mathrm{NaCl}$ içeren LB besi yerinde türbidite oluşumu ve tütünde aşırı duyarlıık (HR) testleri yapılmıştır (Jones ve Geider, 2001; Schaad ve ark., 2001; Lopez ve ark., 2011; EPPO, 2013; Soylu ve ark., 2020).

\section{Ham armut meyvelerinde patojenisite testi}

Hastalık etmeninin izole edildiği alanlarda yaygın olarak yetiştirilen çeşide ait (cv. Santa Maria) ham armut meyveleri çeşme suyu ile yıkandıktan sonra \%1'lik $\mathrm{NaOCl}$ ile 2-3 (dak.) süreyle yüzeysel dezenfeksiyonu yapılmıştır ve steril su ile durulanmıştır. Nemli filtre kâğıtları bulunan petrilere yaklaşık $1 \mathrm{~cm}$ kalınlığında enine dilimlenen ham armut dilimleri üzerine tanılaması yapılacak olan izolatların bakteriyel süspansiyonları $\left(10^{9}\right.$ hücre $\mathrm{ml}^{-1}$ ) $20 \mu \mathrm{l}$ bulaştırıldıktan sonra, petrilere yerleştirilmiş ve sonra hastalık çıkışının gözlenmesi amacıyla $26^{\circ} \mathrm{C}^{\prime}$ de 5 gün inkübatörde bekletilmiştir (Van der Zwet, 1986; EPPO, 2013).

\section{Moleküler tanılama}

LB sIVı besi ortamında 24-48 saatlik süreyle geliştirilen bakteriyel kolonilerden genomik DNA izolasyonu ThermoFisher firması GeneJET Genomik DNA prüfikasyon kiti (Katalog numarası: K0721) kullanılarak yapılmıştır. Nanodrop cihazından elde edilen DNA miktar tayinine göre örneklerin DNA'ları $10 \mathrm{ng}^{-1} \mathrm{l}^{-1}$ final konsantrasyon olacak şekilde hazırlanarak DNA örnekleri $-20^{\circ} \mathrm{C}^{\prime}$ de saklanmıştır. İzolatların PCR ile tanısında G1f/G2r (Taylor ve ark., 2001) ve EAPSGL3961/ EAPSGL4610c (Wensing ve ark., 2012) primerleri kullanılmıştır (Çizelge 1). PCR karışımı, $10 \mu \mathrm{l}$ 2x master mix (Bioline my Taq, İngiltere), $1 \mu$ forward primer (10 pmol), $1 \mu \mathrm{l}$ reverse primer $(10 \mathrm{pmol}), 7 \mu \mathrm{l}$ steril su ve $1 \mu$ l DNA olacak şekilde hazırlanmıştır. Thermocycler cihazı PCR döngü işlemleri, Touchdown (kademeli sıcaklık düşürme) programına göre yapılmıştır. $95^{\circ} \mathrm{C}^{\prime}$ de 4 (dak.), ilk 10 döngü; $94^{\circ} \mathrm{C}^{\prime}$ de 30 (s), $65-56^{\circ} \mathrm{C}^{\prime}$ de 30 (s) (her döngüde $1^{\circ} \mathrm{C}$ azalır), $72^{\circ} \mathrm{C}^{\prime}$ de 1 (dak.), $72^{\circ} \mathrm{C}^{\prime}$ de 5 (dak.) şeklinde ayarlanarak ilaveten 24 döngü sabit $56^{\circ} \mathrm{C}^{\prime}$ de aynı parametreleri kullanarak uygulanmıştır (Aksoy ve ark., 2017).

Çizelge 1. Enfekteli elma ve armut ağaçlarından elde edilen E. amylovora izolatların moleküler tanısında kullanılan primer ve oligonükleotid dizinleri

Table 1. Primers and oligonucleotides sequences used in molecular identification of E. amylovora isolates obtained from infected apple and pear trees

\begin{tabular}{llll}
\hline Tür & Primer adı & $\begin{array}{l}\text { Sekans } \\
\mathbf{5}^{\prime} \boldsymbol{\rightarrow} \mathbf{3}^{\prime}\end{array}$ & $\begin{array}{l}\text { PCR } \\
\text { (bç) }\end{array}$ \\
\hline E. amylovönü \\
\end{tabular}

\section{BULGULAR ve TARTIŞMA}

Hastalığın belirtileri ve il genelinde durumu
Yozgat ili ve bağlı köylerinde yetiştiriciliği yapılan armut ve elma bahçelerinde meyve ağaçları hastalık etmeninin varlığı açısından incelenmiş ve elde edilen sonuçlar 
Çizelge 2'de sunulmuştur. Survey yapılan armut ve elma üretim alanlarındaki enfekteli ağaçlarda hastalık etmeninin tipik olarak yapraklarında koyu kahverengisiyah lekeler, çiçek ve meyve saplarında yanıklık, sürgünlerde aşağı doğru sarkma, baston şeklini alan dallar, ağaç gövdelerinde kuruma, çatlama, kabuk altı dokuda nekroz belirtilerine neden olduğu gözlemlenmiştir (Şekil 1 ve Şekil 2). Yapılan yakın gözlemlerde, armut ağaçlarındaki enfekteli yapraklarda ortaya çıkmış düzensiz koyu siyah renkli nekrozların elma yapraklarındakilere kıyasla daha açık renkte olduğu gözlemlenmiştir (Şekil 1). Armutlarda meyve üzerindeki nekrozların şiddetli enfeksiyonlar nedeniyle oluşan bakteriyel akıntının (eksudat) kurumasından kaynaklandığı düşünülmektedir (Şekil 1B).

Yozgat ili genelinde armut bahçelerinde yapılan surveyler sonucunda ortalama hastalık yaygınlığı \%91 (\%66.6-100.0), bulunma oranı \%20 (\%0-42.0), hastalık şiddeti ise \%29 (\%0-42.0) olarak hesaplanmıştır. Hastalık etmeninin survey yapılan alanlardaki şiddeti ve bulunma oranı açısından en fazla Kadışehri ilçesinde
(\%42.0 ve \%42.0), yaygınlık açısından ise en fazla Merkez, Kadışehri ve Sarıkaya ilçelerinde (\%100) olduğu tespit edilmiştir. Etmenin hastalık şiddeti ve bulunma oranı açısından en az Sarıkaya ilçesinde (\%3.75 ve $\% 0.46)$, yaygınlık ise en az Sorgun ilçesinde (\%66.0) olduğu gözlenmiştir (Çizelge 2). Çekerek ilçesinde yapılan surveylerde armut bahçesi olmaması nedeniyle hastalık etmeni ile bulaşık bahçe kaydedilmemiştir.

Yozgat ili genelinde elma bahçelerinde yapılan surveyler sonucunda ortalama hastalık yaygınlığı \%70.0, bulunma oranı \%0.87, hastalık şiddeti ise \%5.93 olarak hesaplanmıştır. Hastalık etmeninin survey yapılan alanlardaki şiddeti ve bulunma oranı açısından en fazla Çekerek ilçesinde (\%8.2 ve \%1.17), yaygınlık açısından değerlendirildiğinde ise en fazla sorgun ilçesinde (\%80.0) kaydedilmiştir. Hastalığın şiddeti ve bulunma oranı açısından değerlendirildiğinde en az Sarıkaya ilçesinde (\%2.3 ve \%0.2), yaygınlık açısından ise en az Kadışehri ilçesinde (\%33) olduğu belirlenmiştir (Çizelge 2).

Çizelge 2. Yozgat ili genelinde yetiştirilen armut ve elma bahçelerinde bakteriyel ateş yanıklık hastalığın yaygınlığı (P), bulunma oranı (I) ve şiddeti (S).

Table 2. Prevalence (I), incidence (I) and severity (S) of bacterial fire blight disease in pear and apple orchards grown in Yozgat province

\begin{tabular}{|c|c|c|c|c|c|c|}
\hline \multirow[b]{2}{*}{ İlçe } & \multicolumn{4}{|c|}{ Armut } & \multicolumn{2}{|l|}{ Elma } \\
\hline & Yaygınlık (P) & $\begin{array}{l}\text { Bulunma } \\
\text { oranı (I) }\end{array}$ & $\begin{array}{l}\text { Hastalık şiddeti } \\
\text { (S) }\end{array}$ & Yaygınlık (P) & Bulunma oranı (I) & $\begin{array}{l}\text { Hastalık şiddeti } \\
\text { (S) }\end{array}$ \\
\hline Merkez & 100.0 & 3.43 & 13.5 & 71.4 & 0.69 & 4.6 \\
\hline Çekerek & - & - & - & 66.6 & 1.17 & 8.2 \\
\hline Kadışehri & 100.0 & 42.0 & 42.0 & 33.0 & 1.16 & 7.14 \\
\hline Sarıkaya & 100.0 & 0.46 & 3.75 & 66.6 & 0.2 & 2.3 \\
\hline Sorgun & 66.6 & 3.04 & 10.1 & 80 & 1.01 & 5.73 \\
\hline Ortalama & 91.0 & 20.0 & 29.0 & 70.0 & 0.87 & 5.93 \\
\hline
\end{tabular}

-: Survey yapılan alanda armut bahçesi olmaması nedeniyle hastalık gözlenmemiştir.

Yozgat ilinde yapılan gözlemlere göre elmalarda ateş yanıklığı hastalığının yaygınlığı, bulunma oranı ve şiddetinin genelde armutlara kıyasla daha düşük oranlarda olduğu gözlenmiştir. Hastalık, elmalarda Starking Delicious, Golden Delicious ve Pink Lady çeşitlerinde, armutlarda ise Deveci, Williams, Santa Maria çeşitleri ile yerel genotiplerde tespit edilmiştir. Yapılan gözlemlerde elma çeşitleri arasında hastalığa duyarlılık açısından bariz bir farklılık gözlenmemiştir. Armut çeşitleri arasından Santa Maria çeşidinde hastalığın daha şiddetli belirtiler oluşturduğu gözlemlenmiştir. Dolu yağışları ve don olaylarının yoğun olarak görüldüğü bölgelerdeki ağaçlarda ateş yanıklığı enfeksiyonlarının daha fazla tespit edildiği çalışmalarımızda, Kadışehri ilçesinde yer alan meyve bahçelerinde hastalığın yaygın ve şiddetli oranlarda ortaya çıkması sonucunda armut ağaçlarının oluşan şiddetli enfeksiyonlar sebebiyle sökülmek zorunda kalındığı gözlenmiştir.

Ateş yanıklığı hastalığına neden olan E. amylovora patojeninin ülkemiz dahil birçok ülkede ekonomik kayıplara neden olduğu rapor edilmiştir. E. amylovora etmeninin Türkiye'de ilk kez armut ağaçlarında hastalığa neden olduğunun belirlenmesinin ardından (Öktem ve Benlioğlu, 1988) ateş yanıklığı hastalığının birçok bölgemizde elma, armut ve ayva bitkilerinde başlıca kayıpların sorumlusu olduğu rapor edilmiştir (Tokgönül ve Çınar, 1991; Momol ve Yeğen, 1992; 
Demir ve Gündoğdu, 1993; Baştaş ve Katırcıoğlu, 1999; Yahyaoğlu, 1998; Hepaksoy ve ark., 1999; Mirik, 2000; Aysan ve ark., 2006; Atasagun, 2009; Tunalı ve Mirik, 2014). Yozgat ili elma ve armut üretim alanlarında $E$. amylovora etmenin varlığına yönelik daha önceden yapılmış kapsamlı bir çalışma bulunmamaktadır. Benlioğlu ve Özakman (1999), 27 il'de yapılan surveylerde, Yozgat ilinden 1987 yılında toplanan hastalıklı ayva örneğinden izole edildiği belirtilen Eay117 izolatını biyokimyasal yöntemlerle E. amylovora olarak tanılamıştır. Van bölgesinde hastalığın armutlarda sadece sürgünlerde olmadığını çiçek, yaprak, dal ve meyvelerde de enfeksiyona neden olduğunu, hastalıklı yaprak, dal ve sürgünlerden yapılan izolasyon çalışmaları enfeksiyon kaynağının $E$. amylovora olduğu belirlenmiştir (Öden, 1998).
Çıtır ve Mirik (1999), Amasya ve Tokat illeri elma, armut ve ayva üretim alanlarında $E$. amylovora'nın bölgede \%14.42 oranında enfeksiyon oluşturduğunu bildirmiştir. Momol ve Yeğen (1992), ateş yanıklığı hastalığının elmalarda yaygınlığı ve hastalık şiddetinin armutlara kıyasla daha düşük oranda olduğunu bildirmişlerdir. Konya ilinde armut ağaçlarında hastalığın bulunma oranı ve yaygınlığının $\% 57.80$ ve $\% 83.80$, elma ağaçlarında bu değerlerin sırasıyla \%22.40 ve \%50.90 oranlarda olduğunu belirlemişlerdir (Baştaş ve Katırcıoğlu, 1999). Bu çalışmada, 30 farklı elma ve 11 farklı armut bahçesinde yapılan surveyler sonucunda toplam 1890 elma ve 820 armut ağacı ateş yanıklığı hastalığının varlığı açısından incelenmiş olup önceki çalışmalarda belirtildiği gibi hastalığın armut ağaçlarında daha tahripkâr olduğu belirlenmiştir.

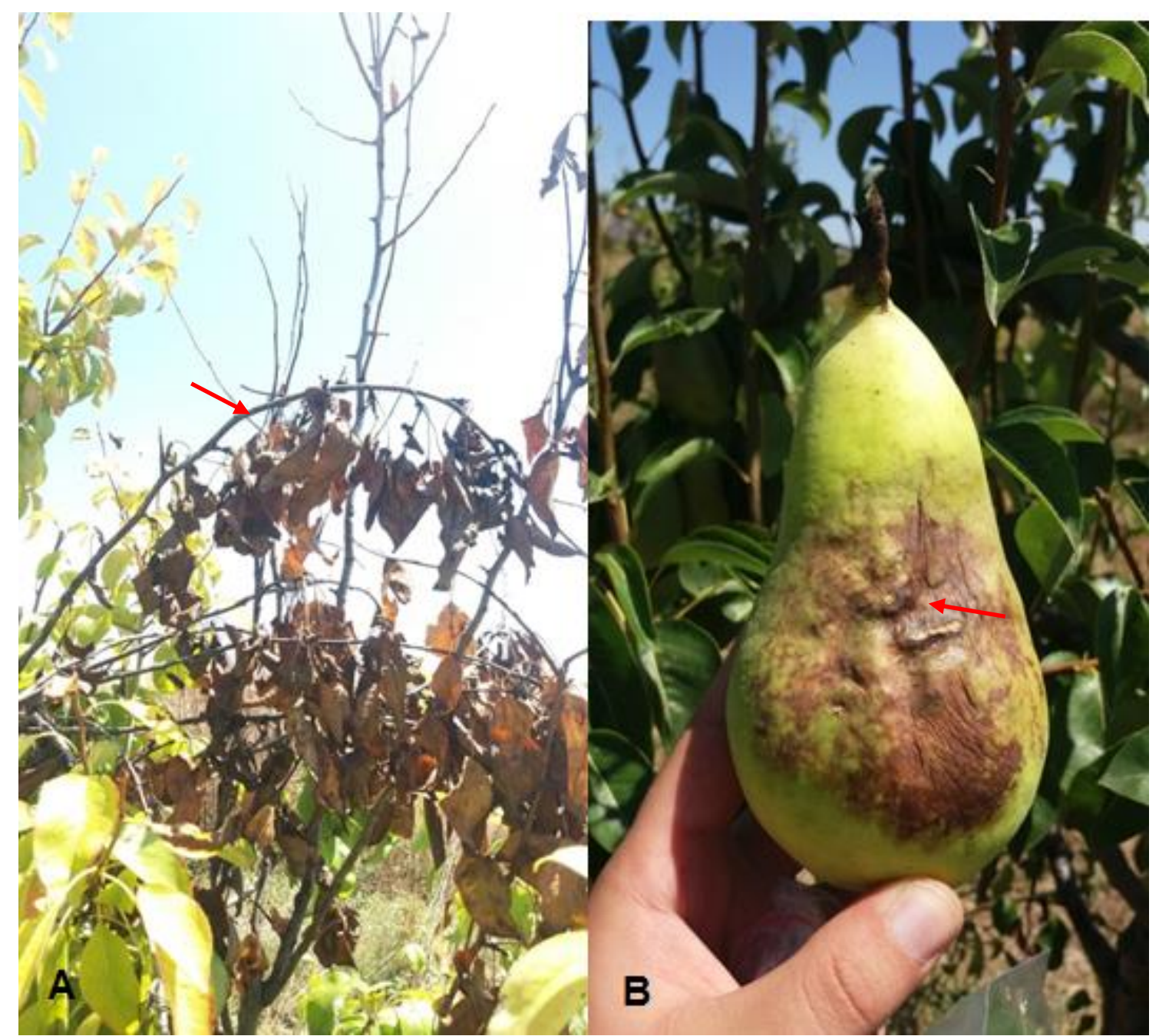

Şekil 1. (A) Hastalık etmeni tarafından enfekteli armut ağacında neden olunan tipik sürgün ve dal yanıklı̆̆ı (ok) belirtileri (B) Armut meyvesinde bakteriyel akıntının kuruması sonucu oluşan nekrotik belirtileri (ok).

Figure 1. (A) Typical blight symptoms (arrow) on shoots and branches of infected pear tree (B) Necrotic tissue formed after the drying out of bacterial ooze (arrow) on the pear fruit. 


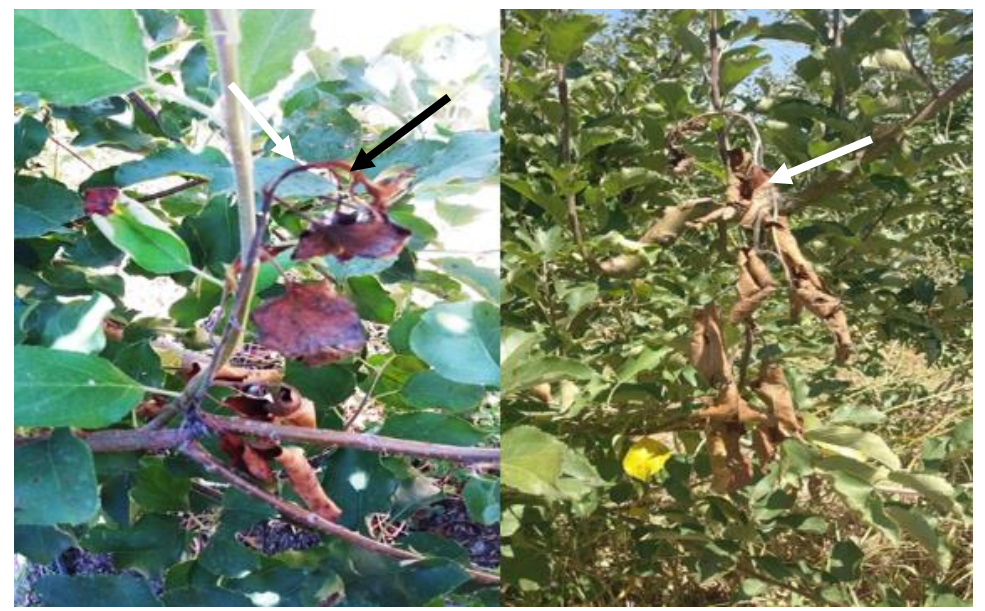

Şekil 2. Enfekteli elma ağacı sürgünlerinde hastalık etmeni $E$. amylovora tarafından oluşturulan tipik kurumalar ve baston şekilli belirtiler (ok)

Figure 2. Typical drying and shepherd's crook (arrow) disease symptoms caused by E. amylovora on infected apple tree shoots

\section{Hastalık etmeninin izolasyonu ve tanılanması}

Survey yapılan bahçelerden tipik hastalık belirtisi gösteren 45 farklı enfekteli örnekten 86 adet bakteriyel koloni saflaştırılmıştır (Şekil 3). Tek koloniden saflaştırılmış izolatların tamamı EPPO tarafından tavsiye edilen protokollere ilave olarak standart morfolojik, biyokimyasal, fizyolojik ve moleküler testlere tabi tutulmuştur (Klement ve ark., 1964; Schaad ve ark., 2001; EPPO, 2013).
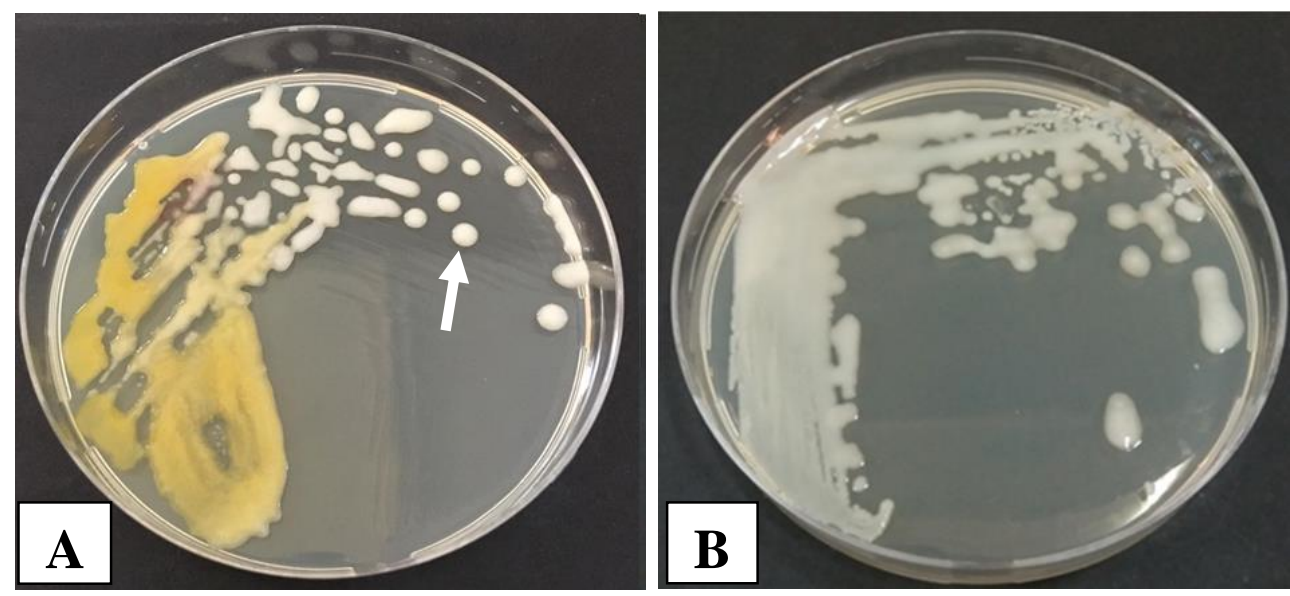

Şekil 3. (A) Hastalıklı bitkilerden izole edilen farklı morfolojik yapılı bakteri ve E. amylovora kolonileri (ok). (B) Izolasyon petrilerinden saflaştırılan E. amylovora EA7 izolatın KB besi yerinde saf kültürü.

Figure 3. (A) Morphological appearance of different bacterial and E. amylovora colonies (arrow) isolated from infected plants on isolation plates. (B) Shows typical appearance of pure culture of E. amylovora EA7 isolate on $K B$ nutrient medium.

Bitki patojenlerinin hızlı, güvenilir tanısı ve çok yakın olduğu epifitik izolatlardan ayrılması, hastalık kontrolü ve uygun mücadele yöntemlerinin uygulanabilmesi için çok önemlidir. Survey çalışmalarında elde edilen farklı morfolojik görünüşteki tüm izolatların tamamı öncelikle moleküler yöntemlerin uygulandığı PCR çalışmalarında kullanılmıştır. Wensing ve ark. (2012) tarafından geliştirilen ve çalışmalarımızda kullanılan EAPSGL3961/EAPSGL4610c primer çiftinin, hastalık etmeni $E$. amylovora'nın patojenik olmayan $E$. tasmaniensis (Geider ve ark., 2006) ve E. billingiae (Mergaert ve ark., 1999) ile Asya armutlarında sürgün yanıklığına neden olan $E$. pyrifoliae etmeninden (Kim ve ark., 1999) başarılı bir şekilde ayrımında kullanılalarak 649 (bç) bant oluşturduğu bildirilmiştir. Şahin ve ark., (2019) ayva izolatlarının, Kıpçak ve Akköprü (2017) elma izolatlarının PCR ile tanısında G1f/G2r primerlerini (Taylor ve ark., 2001) kullanarak E. amylovora 
izolatlarının 187 (bç) spesifik PCR ürününü oluşturduğunu bildirmişlerdir. Çalışmalarımızda elde edilen izolatların PCR ile moleküler tanılama çalışmalarında da EAPSGL3961/EAPSGL4610c ile G1f/G2r primerleri kullanılmış ve beklenen 649 ve 187 (bç) PCR ürünleri (Şekil 4) elde edilmiştir (Taylor ve ark., 2001; Dardouri ve ark., 2017).

Test edilen 86 bakteri izolatları arasından 11 elma ve 9 armut izolatının G1f/G1r ve EAPSGL3961/EAPSGL4610c primerleri kullanılmak suretiyle yapılan PCR çalışmaları sonucunda, $E$. amylovora etmenine spesifik beklenen PCR ürünlerinin oluşturulduğu gözlenmiştir (Şekil 4). Böylece 11 elma ve 9 armut izolatının morfolojik, biyokimyasal ve fizyolojik testleri türe spesifik primerler ile teyit edilerek kesin tür tanıları yapılmıştır.

PCR analizlerinde beklenen bantları oluşturan 20 izolatın King $B$ agar besi yerinde beyaz-krem renkte yüksek bombeli (Şekil 3), Sukroz Nutrient Agar (SNA) besiyerinde mukoid levan tipte koloni gelişimine sahip olduğu belirlenmiştir. dehidrolaz, indol oluşumu, patateste pektolitik aktivite testlerine negatif, jelatinin hidrolizi testine pozitif reaksiyon göstermiştir. Fakültatif anaerobik izolatların $36^{\circ} \mathrm{C}$ gelişme gösteremediği, \%5'lik $\mathrm{NaCl}$ içeren LB besi yerinde türbidite oluşturduğu belirlenmiştir. Test edilen 20 izolatın tamamı, tütün yapraklarında aşırı duyarlılık reaksiyonuna neden olmuştur (Çizelge 3). Söz konusu 20 izolat ayrıca ham armut dilimleri üzerinde yapılan patojenisite testinde, kahverengileşme ve karakteristik kremsi damlacık (ooze, bakteriyel akıntı) oluşumuna neden olmuştur. Elde edilen izolatlar biyokimyasal ve fizyolojik karakterleri tipik EPPO tarafından belirtilen $E$. amylovora özelliklerini göstermiştir (EPPO, 2013). Hastalık etmeninin morfolojik, biyokimyasal, fizyolojik ve moleküler testlerinden elde edilen sonuçlar daha önce aynı etmen ile yapılmış farklı çalışmalarda bildirilen sonuçlarla benzerlik göstermiştir (Benlioğlu ve Özakman, 1999; Baştaş ve Katırcıoğlu, 1999; Jones ve Geider, 2001; Lopez ve ark., 2011; Tunalı ve Mirik, 2014, Kıpçak ve Akköprü, 2017; Şahin ve ark., 2019).

Testlerde kullanılan 20 izolat, $\mathrm{KOH}$, oksidaz, arginine

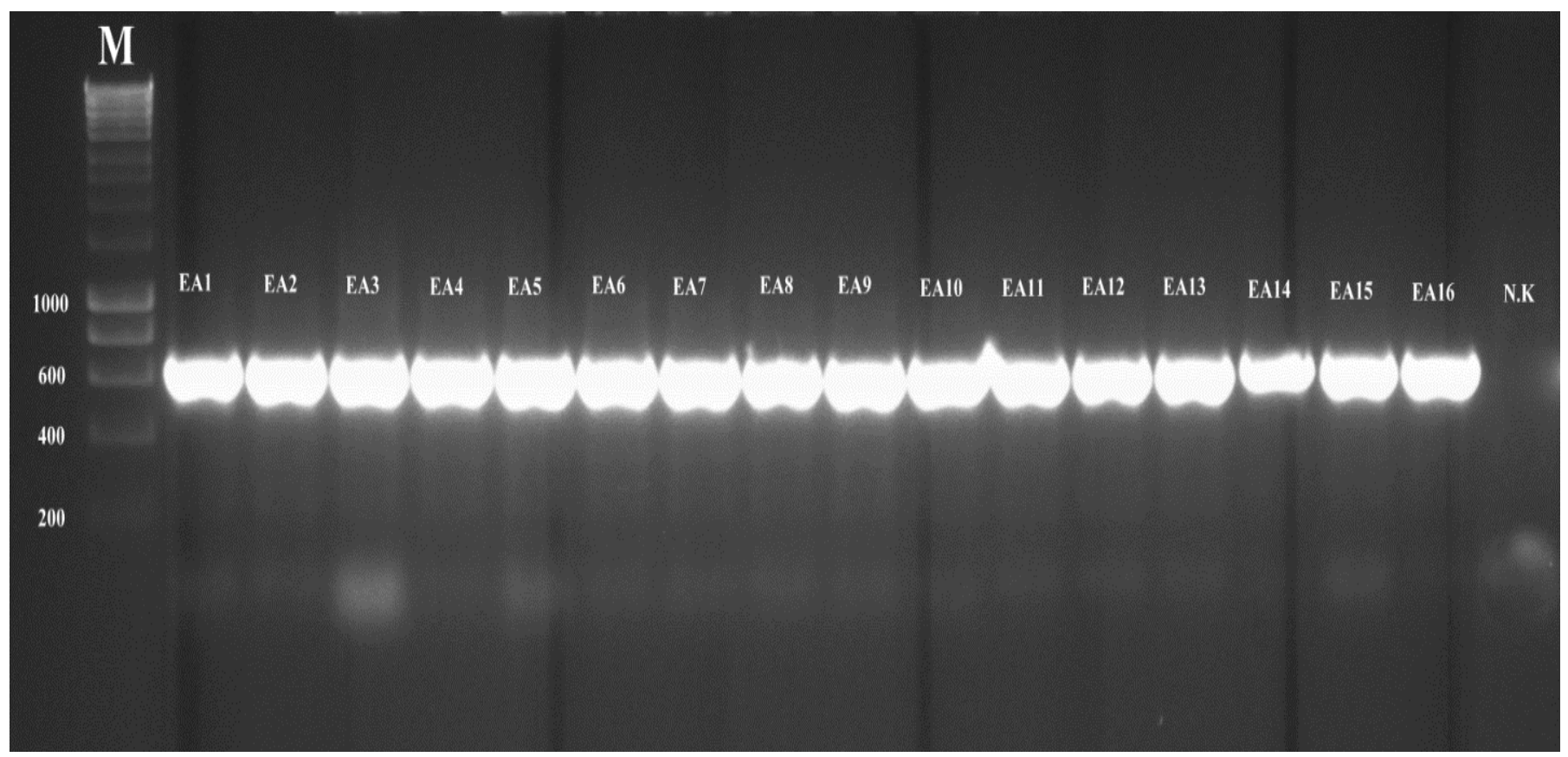

Şekil 4. E. amylovora izolatların EAPSGL39617/EAPSGL4610c primer çifti kullanılmak suretiyle çoğaltılan 649 bç büyüklüğündeki $P C R$ ürününün agaroz jel üzerindeki görünümü.

Figure 4. Appearance of amplified 649 bp PCR product of $E$. amylovora isolates by using EAPSGL39617/EAPSGL4610c primers on agarose gel. 
Çizelge 3. E. amylovora izolatlarının biyokimyasal, fizyolojik ve patojenisite test sonuçları. Table 3. Biochemical, physiological and pathogenicity test results of E. amylovora isolates

\begin{tabular}{|c|c|c|c|c|c|c|c|c|c|c|c|c|c|c|}
\hline$\frac{\mathbb{\pi}}{0}$ & $\stackrel{\mathscr{N}}{=}$ & :ఫे & 咅 & 疍 & $\begin{array}{l}\text { 듬 } \\
\underline{y}\end{array}$ & $\begin{array}{l}\frac{N}{\mathrm{~N}} \\
\frac{\mathrm{O}}{\mathrm{V}} \\
\frac{\mathrm{y}}{0}\end{array}$ & 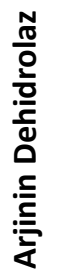 & 芩 & 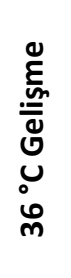 & 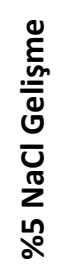 & 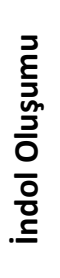 & 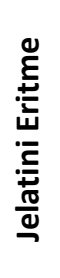 & 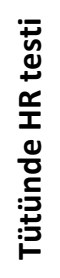 & 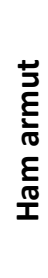 \\
\hline Ea1 & Merkez & Fakıbeyli & Elma & + & + & - & - & $\mathrm{F}$ & - & + & - & + & + & + \\
\hline Ea2 & Merkez & İnceçayır & Elma & + & + & - & - & $\mathrm{F}$ & _ & + & - & + & + & + \\
\hline Ea3 & Merkez & Başıbüyüklü & Elma & + & + & - & - & $\mathrm{F}$ & - & + & - & + & + & + \\
\hline Ea4 & Çekerek & Merkez & Elma & + & + & - & - & $\mathrm{F}$ & - & + & - & + & + & + \\
\hline Ea5 & Çekerek & Kesikköprü & Elma & + & + & - & - & $\mathrm{F}$ & - & + & - & + & + & + \\
\hline Ea6 & Kadışehri & Kabala & Elma & + & + & - & - & $\mathrm{F}$ & - & + & - & + & + & + \\
\hline $\mathrm{Ea} 7$ & Sarıkaya & Merkez & Elma & + & + & - & - & $\mathrm{F}$ & - & + & - & + & + & + \\
\hline Ea8 & Sorgun & Akoluk & Elma & + & + & - & - & $\mathrm{F}$ & - & + & - & + & + & + \\
\hline Ea9 & Sorgun & Merkez & Elma & + & + & - & - & $\mathrm{F}$ & - & + & - & + & + & + \\
\hline Ea10 & Sorgun & Gedikhasanlı & Elma & + & + & - & - & $\mathrm{F}$ & - & + & - & + & + & + \\
\hline Ea11 & Sorgun & Kepirce & Elma & + & + & - & - & $\mathrm{F}$ & - & + & - & + & + & + \\
\hline Ea12 & Merkez & Fakıbeyli & Armut & + & + & - & - & $\mathrm{F}$ & - & + & - & + & + & + \\
\hline Ea13 & Merkez & İnceçayır & Armut & + & + & - & - & $\mathrm{F}$ & - & + & - & + & + & + \\
\hline Ea14 & Kadışehri & Kabala & Armut & + & + & - & - & $\mathrm{F}$ & - & + & - & + & + & + \\
\hline Ea15 & Kadışehri & Kabala & Armut & + & + & - & - & $\mathrm{F}$ & - & + & - & + & + & + \\
\hline Ea16 & Kadışehri & Kabala & Armut & + & + & - & - & $\mathrm{F}$ & - & + & - & + & + & + \\
\hline Ea17 & Kadışehri & Kabala & Armut & + & + & - & - & $\mathrm{F}$ & _ & + & - & + & + & + \\
\hline Ea18 & Sarıkaya & Merkez & Armut & + & + & - & - & $\mathrm{F}$ & - & + & - & + & + & + \\
\hline Ea19 & Sorgun & Gedikhasanlı & Armut & + & + & - & - & $\mathrm{F}$ & - & + & - & + & + & + \\
\hline Ea20 & Sorgun & Kepirce & Armut & + & + & - & - & $\mathrm{F}$ & - & + & - & + & + & + \\
\hline
\end{tabular}

\section{Sonuç ve Öneriler}

Bu çalışma ile bitkilerde en önemli bakteriyel hastalık etmenleri arasında yer alan, başta armut, elma ve ayva gibi ekonomik öneme sahip bitkilerde verim ve kalite kayıplarına yol açan hatta büyük yatırımların son bulmasına bile neden olabilecek E. amylovora hastalık etmeninin Yozgat ilindeki mevcut durumu, hastalıklı bitki örneklerinden bakteriyel etmenin izolasyonu, izolatların biyokimyasal, patojenisite ve moleküler çalışmalarla tanılanmasıyla ortaya konulmuştur.

Etmenle mücadelede epidemiyolojik araştırmalara başlanılmalı ve Türkiye'de elma ve armut bölgelerine uygun tahmin sistemleri geliştirilmelidir (Momol, 1990). Karahan ve ark. (2013), Ankara ve Tokat illerinde erken uyarı sistemlerinin hem enfeksiyon risk günlerini hem de belirti çıkış tarihleri belirlemede başarılı olarak kullanılabileceğini ve hastalıkla etkin bir şekilde mücadele edilebileceğini bildirmişlerdir. Üreticilerin hastalıklarla mücadelede bölgeye uygun çeşit seçimi yapması gerekmektedir. Çıtır ve Mirik (1999), Amasya ve Tokat bölgesinde yabani armutların standart çeşitlere göre daha hassas olduğunu ayrıca geçci çeşitlerde hastalı̆̆ın daha az görüldüğünü elmalarda ise erkenci çeşitlerin hastalığa daha duyarlı olduğunu bildirmiştir. Baştaş ve Katırcıoğlu (1999), kimyasalların hastalığın şiddetini azaltabileceğini ve entegre mücadelede kullanılabileceğini bildirmiştir. Hastalığın etkin mücadelesinde henüz etkili kimyasallar bulunmadığını dayanıklı anaç ve çeşit kullanımının hastalıktan kaynaklı kayıpları büyük ölçüde azaltacağı bildirilmektedir (Evrenosoğlu ve ark., 2014; Mertoğlu ve Evrenosoğlu, 2017). Ülkemizde yapılan biyolojik mücadele çalışmalarında, maya ve bakteriyel biyoformulasyonların kimyasallara göre çiçek enfeksiyonlarının önlenmesinde daha başarılı olduğu belirlenmiştir (Özaktan ve Bora, 2004; Aktepe, 2017). Doğu Anadolu bölgesinde yapılan bir diğer çalışmada, Karabıçak ve Kotan (2014) armut ağaçlarına yeşil aksam uygulamalarında biyolojik mücadele etmenlerinin hastalık gelişiminin engellenmesi üzerine önemli etkisinin olduğunu, biyopreparat uygulamalarının daha sık aralıklarla yapılması durumunda antagonist bakterilerinin etkinliğinin daha da artırılabileceğini bildirmişlerdir.

Elde edilen sonuçlar, E. amylovora hastalık etmenin Yozgat ili genelinde yetişen armut ve elma 
bahçelerindeki mevcut durumunu ortaya koyan detaylı ilk çalışmadır. Hastalık etmeninin bölgedeki yaygınlık durumu yeni tesis edilecek bahçe ve yatırımlar ile mevcut devam eden üretim alanlarında göz önünde bulundurulması büyük bir önem arz etmekte olup, hastalığın bölgedeki yaygınlık durumuna uygun olarak mücadele önlemlerinin alınması gerekmektedir.

\section{ÖZET}

Amaç: Bu çalışma, 2018 yılında Yozgat ili elma ve armut üretim alanlarında bakteriyel ateş yanıklığı hastalığının mevcut durumunu belirlemek amacıyla yapılmıştır.

Yöntem ve Bulgular: Survey yapılan elma ve armut bahçelerindeki ağaçlar hastalık yönünden değerlendirilmiş, enfekteli bitkilerden hastalık etmeni izole edilerek, morfolojik, biyokimyasal, fizyolojik ve moleküler yöntemlerle teşhis edilmiştir. Enfekteli 45 farklı bitki örneğinden elde edilen 86 bakteri izolatı arasından 20 izolatın morfolojik, biyokimyasal, fizyolojik ve moleküler testlemeler sonucunda Erwinia amylovora olduğu belirlenmiştir. Survey yapılan armut bahçelerinde hastalık yaygınlığı \%91, bulunma oranı $\% 20$, hastalık şiddeti \%29 düzeyinde olup, elma bahçelerinde hastalığın yaygınlığı \%70, bulunma oranı $\% 0.87$, hastalık şiddeti \%5.93 düzeyinde olduğu belirlenmiştir.

Genel Yorum: Hastalığın Yozgat ili genelinde armut ağaçlarında elma ağaçlarına kıyasla daha yaygın sıklıkta görüldüğü, benzer şekilde hastalık şiddetinin armut ağaçlarında elma ağaçlarına göre daha yüksek düzeyde olduğu belirlenmiştir.

Çalışmanın Önemi ve Etkisi: Elde edilen sonuçlar hastalığın Yozgat ilinde mevcut durumunu ortaya koyarken, armut ağaçlarında ciddi sorunlara neden olması nedeniyle yeni tesis edilen bahçelerde hastalığa karşı ciddi tedbirlerin alınmasının gerekliliği bu çalışma ile bir kez daha öne çıkmıştır.

Anahtar Kelimeler: Bakteriyel hastalık, ateş yanıklı̆ı, Erwinia amylovora, Yozgat ili, moleküler tanı.

\section{TEŞEKKÜR}

Bu çalışma Yozgat Bozok Üniversitesi Bilimsel Araştırma Projeleri Komisyonu Başkanlığı tarafından finansal olarak desteklenmiştir (Proje Numarası: 6602c-ZF/18190).

\section{ÇIKAR ÇATIŞMA BEYANI}

Makale yazarları aralarında herhangi bir çıkar çatışması olmadığını beyan ederler.

\section{ARAŞTIRMACILARIN KATKI ORANI BEYANI}

Yazarlar makaleye eşit oranda katkı sağlamış olduklarını beyan ederler.

\section{KAYNAKLAR}

Agrios GN (2005) Plant Pathology. $5^{\text {th }}$ Edition, Academic Press, $922 \mathrm{pp}$.

Anonim

http://oran.org.tr/images/dosyalar/2017091509091 0 0.pdf. Erişim tarihi: 28 Ocak 2018.

Aksoy HM, Kaya Y, Ozturk M, Secgin Z, Onder H, Okumus A (2017) Pseudomonas putida-Induced response in phenolic profile of tomato seedlings (Solanum lycopersicum L.) infected by Clavibacter michiganensis subsp. michiganensis. Biological Control 105: 6-12.

Aktepe BP, Aysan Y, Tepe S (2014) Determination of fire blight susceptibility of loquat cultivars. Acta Horticulture 1056: 231-233.

Aktepe BP (2017) Erwinia amylovora'nın biyolojik mücadelesinde epifitik bakteri ve mayaların etkilerinin araştırılması. Doktora Tezi, Çukurova Üniversitesi, Fen Bil. Ens., Bitki Koruma ABD, 109 s.

Atasagun R (2009) Rosaceae familyasindaki farklı bitki türlerinden elde edilen Erwinia amylovora (Burr.) Winslow et al.'nin biyokimyasal ve polimeraz zincir reaksiyonu (PCR) testleriyle tanılanması. Yüksek Lisans Tezi, Selçuk Üniversitesi, Fen Bil. Ens., Bitki Koruma ABD, $93 \mathrm{~s}$.

Aysan Y, Mirik M, Sahin F, Kotan R, Saygili H (2006) Phenotypic characterization of Erwinia amylovora from pome fruits in Turkey. Acta Hortic. 704: 459464.

Bashimov G (2016) Elma ihracatında Türkiye'nin karşılaştırmalı üstünlüğü. Adnan Menderes Üniversitesi, Zir. Fak. Derg. 13(2): 9-15.

Baştaş KK, Katircioglu YZ (1999) Studies on fire blight (Erwinia amylovora (Burr.) Winslow et al.) on pome fruit trees in Konya province in Turkey. Acta Hortic. 489: 111-114.

Baştaş KK (2012) First Report of Erwinia amylovora on Firethorn (Pyracantha coccinea) Mountainash (Sorbus sp.) in Turkey. Plant Dis. 96(12): 1818-1818.

Baştaş KK, Sahin F (2014) First report of fire blight caused by Erwinia amylovora on meadowsweet (Spirea prunifolia) in Turkey. Plant Dis. 98(1): 153153.

Benlioğlu K, Özakman M (1999) Characterization of Turkish isolates of Erwinia amylovora (burr.) Winslow et al. Acta Hortic. 489: 127-132. 
Bora T, Karaca I (1970) Kültür bitkilerinde hastalığın ve zararın ölçülmesi. E.Ü. Zir. Fak., Yayın no 167, İzmir, 42.

Cabrefiga J, Montesinos E (2005) Analysis of aggressiveness of Erwinia amylovora using diseasedose and time relationships. Phytopathol. 95(12): 1430-1437.

Çıtır A, Mirik M (1999) Fire blight of pome fruits and search for resistant or tolerant cultivars in Amasya and Tokat Regions in Turkey. Acta Hortic. 489: 215220.

Dardouri S, Chehimi S, Murillo Martínez J, Hajlaoui MR. (2017) Molecular characterization of Tunisian strains of Erwinia amylovora. J. Plant Pathol. 99(2): 331337.

Demir G, Gündogdu M (1993) Fireblight of pome fruit trees in Turkey: Distribution of the disease, chemical control of blossom infections and susceptibility of some cultivars. Acta Hortic. 338, 67-74.

EPPO (2013) PM 7/20 (2) Erwinia amylovora. EPPO Bulletin 43(1): 21-45.

Evrenosoğlu Y, Mısırlı A, Aysan Y, Saygılı H, Boztepe Ö, Horuz S, Acarsoy N, Bilen E, Baykul A, Yazıcı I (2014) F1 Melez armut populasyonunun ateş yanıklığı hastalığı etmeni Erwinia amylovora karşı reaksiyonunun belirlenmesi. Ege Üni. Zir. Fak. Derg. 51(2): 185-190

FAO (2018) FAOSTAT, Word Production Quantities of Apple and Pear. http://www.fao.org/faostat/en/\#data/QC/visualize. Erişim Tarihi: 28 Kasım 2020.

Geider K, Auling G, Du Z, Jakovljevic V, Jock S, Völksch B (2006) Erwinia tasmaniensis sp. nov., a nonphytopathogenic bacterium from apple and pear trees. Int. J. Syst. Evol. Microbiol. 56(12): 2937-2943.

Gül M, Akpınar MG (2006) Dünya ve Türkiye meyve üretimindeki gelişmelerin incelenmesi. Akdeniz Üni. Zir. Fak. Derg. 19: 15-27.

Hepaksoy S, Ünal A, Can HZ, Saygili H, Türküsay H (1999) Distribution of fire blight (Erwinia amylovora (Burrill) Winslow et al.) disease in Western Anatolia region in Turkey. Acta Hortic. 489: 193-196.

Jones AL, Geider K (2001) Erwinia amylovora group. In: Laboratory Guide for Identification of Plant Pathogenic Bacteria (Eds. Schaad NW, Jones JB, Chun W), $3^{\text {rd }}$ ed., APS press, St. Paul, MN, USA. 4054.

Karabıçak Y, Kotan R (2014) Armut ağaçlarında Ateş Yanıklığı etmeni Erwinia amylovora (Burrill) Winslow et al.'ya karşı bakteri uygulamaları ile biyolojik mücadele imkânlarının araştırılması. Bitki Koruma Bülteni 54(4): 355-370.
Karahan A, Özakman M, Altundağ \$̧ (2013) Ankara ve Tokat'ta elma ve armut bahçelerinde Ateş yanıklığı hastalığının [Erwinia amylovora (Burrill) Winslow et al.] enfeksiyon risk günlerinin belirlenmesinde tahmin modellerinin kullanılması üzerine çalışmalar. Bitki Koruma Bülteni 53(4): 207-238.

Klement Z, Farkas GL, Lovrekovich L (1964) Hypersensitive reaction induced by phytopathogenic bacteria in the tobacco leaf. Phytopathol. 54: 474477.

King EO, Ward MK, Raney DE (1954) Two simple media for the demonstration of pyocyanin and fluorescein. J. Lab. Clin. Med. 44: 301-307.

Kıpçak C, Akköprü A (2017) The fire blight problem on apples in Lake Van basin: The status and incidence of the disease. Yüzüncü Yıl Üni. J. Agri. Sci. 27(2): 204211.

Kim WS, Gardan L, Rhim SL, Geider K (1999) Erwinia pyrifoliae sp. nov., a novel pathogen that affects Asian pear trees (Pyrus pyrifolia Nakai). Int. J. Syst. Evol. Microbiol. 49(2): 899-906.

Lopez MM, Rosello M, Llop P, Ferrer S, Christen R, Gardan L (2011) Erwinia piriflorinigrans sp. nov., a novel pathogen that causes necrosis of pear blossoms. Int. J. Syst. Evol. Microbiol. 61(3): 561567.

Mansfield JW, Genin S, Magori S, Citovsky V, Sriariyanum $M$, Ronald $P$, Dow $M$, Verdier $V$, Beer SV, Machado MA, Toth I, Salmond G, Foster GD (2012) Top 10 plant pathogenic bacteria in molecular plant pathology. Mol. Plant Pathol. 13(6): 614-629.

Mergaert J, Hauben L, Cnockaert MC, Swings J (1999) Reclassification of non-pigmented Erwinia herbicola strains from trees as Erwinia billingiae sp. nov. Int. J. Syst. Evol. Microbiol. 49(2): 377-383.

Mertoğlu K, Evrenosoğlu Y (2017) Ateş Yanıklığı (Erwinia amylovora) hastalığına dayanıklılık ıslahında, hastalığa karşı testlenmiş F1 melez armut popülasyonunun fenolojik ve meyve özellikleri. Tekirdağ Zir. Fak. Derg. 14: 104-115.

Mirik M (2000) Amasya ve Tokat illerinde yumuşak çekirdekli meyve ağaçlarındaki ateş yanıklığı (Erwinia amylovora (Burr.) Winslow et al.) hastalığının oranı, duyarlı ve dayanıklı çeşitlerin tespiti. Yüksek Lisans Tezi, Trakya Üniversitesi, Fen Bil. Ens., Bitki Koruma ABD, $82 \mathrm{~s}$.

Momol MT (1990) Ateş yanıklığının epidemiyolojisi ve mücadelesi. Akdeniz Üni. Zir. Fak. Derg. 3: 25-38.

Momol MT, Zeller W (1992) Identification and spread of Erwinia amylovora on pear in Turkey. Plant Dis. 76(11): 1114-1116. 
Momol MT, Yegen O (1993) Fire blight in Turkey: 19851992. Acta Hortic. 338: 37-40.

Öden S (1998) Occurrence of fire blight in pear trees grown in Van and around. Acta Hortic. 489: 107-110.

Öktem Y, Benlioğlu K (1988) Studies on fire blight (Erwinia amylovora (Burr.) Winslow et al.) of pome fruits. J. Turk. Phytopathol. 17(3): 106.

Özaktan H, Bora T (2004) Biological control of fire blight in pear orchards with a formulation of Pantoea agglomerans strain Eh 24. Braz. J. Microbiol. 35(3): 224-229.

Rosselo M, Pefialver J, Llop P, Gorris MT, Chartier R, Garcia F, Monton C, Cambra M, Lopez MM (2006) Identification of an Erwinia sp. from different Erwinia amylovora and responsible for necrosis on pear Blossoms. Can. J. Plant Pathol. 28: 30-41

Schaad NW, Jones JB, Chun W (2001) Laboratory Guide for the Identification of Plant Pathogenic Bacteria (No. Ed. 3). American Phytopathological Society (APS Press).

Sobiczewski P, Deckers T, Pulawska J (1997) Fire Blight (Erwinia amylovora): Some aspects of epidemiology and control. RIPF, Skierniewice/Poland. $71 \mathrm{~s}$.

Soylu EM, Soylu S, Kara M, Kurt Ş (2020) Sebzelerde sorun olan önemli bitki fungal hastalık etmenlerine karşı vermikomposttan izole edilen mikrobiyomların in vitro antagonistik etkilerinin belirlenmesi. Kahramanmaraş Sütçü İmam Üni. Tarım ve Doğa Derg. 23: 7-18.

Şahin M, Mısırlı A, Özaktan H (2019) Ege ve Doğu Marmara Bölgesi ayva plantasyonlarında ateş yanıklığı hastalığının değerlendirilmesi. Anadolu Ege Tar. Araş. Ens. Derg. 29(1): 1-14.

Taylor RK, Gulford PJ, Clark RG, Hale CN, Forster RLS (2001) Detection of Erwinia amylovora in plant material using novel polymerase chain reaction (PCR) primers. N. Z. J. Crop Hortic. Sci. 29: 35-43.

Tokgönül S, Çınar Ö (1991) Doğu Akdeniz bölgesinde armutlarda ateş yanıklığı hastalığı (Erwinia amylovora (Burr.) Winslow et al.)'nın tanısı ve yaygınlık durumu üzerinde araştırmalar. VI. Türkiye Fitopatoloji Kongresi Bildirileri, Ekim 7-11, İzmir, Türkiye. pp 303-306.
Tunalı N (2013) Bursa ve Yalova illerinde yumuşak çekirdekli meyve ağaçlarında ateş yanıklığı hastalı̆ı̆na neden olan Erwinia amylovora (Burr.) Winslow et al. izolatlarının bakır sülfat ve streptomisine olan duyarlılık düzeylerinin araştırılması. Yüksek Lisans Tezi, Namık Kemal Üni., Fen Bil. Ens., Bitki Koruma ABD, 97 s.

Tunalı N, Mirik M (2014) Diagnostics of Erwinia amylovora (Burr.) Winslow et al. isolates causing fire blight in pome fruit trees in Bursa. Acta Hortic. 1056: 137-140.

TUiK (2016) Türkiye İstatistik Kurumu. https://biruni.tuik.gov.tr/bitkiselapp/bitkisel.zul.

Erişim Tarihi: 23 Kasım 2019

Uzer S (2017) Ordu ilinde elma ağaçlarında ateş yanıklı̆̆ı hastalığına neden olan Erwinia amylovora etmeninin izolasyonu, tanısı ve yaygınlığının belirlenmesi, Yüksek Lisans Tezi, Ondokuz Mayıs Üni., Fen Bil. Ens., Bitki Koruma ABD, $69 \mathrm{~s}$.

Van der Zwet T (1986) Identification, symptomatology, and epidemiology of fire blight on Le Conte pear in the Nile Delta of Egypt. Plant Dis. 70(3): 230-234.

Van der Zwet T, Keil, HL (1979) Fire blight a bacterial disease of rosaceous plants. United Department Of Agricultural Handbook Number:510, Washington DC, pp. 21-35.

Van der Zwet, T, Beer SV (1992) Fire blight: its nature, prevention, and control: a practice guide to integrated disease management. Agriculture Information Bulletin (USA).

Van der Zwet T, Bonn WG (1999) Recent spread and current worldwide distribution of fire blight. Acta Hortic. 489: 167-168.

Wensing A, Gernold M, Geider K (2012) Detection of Erwinia species from the apple and pear flora by mass spectroscopy of whole cells and with novel PCR primers. J. App. Microbiol. 112(1): 147-158.

Yahyaoğlu MM (1998) Bursa yöresinde ateş yanıklı̆̆ı (Erwinia amylovora (Burr.) Winslow et al.) üzerinde çalışmalar. Yüksek Lisans Tezi, Uludağ Üni., Fen Bil. Ens., Bitki Koruma ABD, 55 s. 